Jurnal Manajemen, Ide, Inspirasi (MINDS)

Vol.5, No. 1, (Januari-Juni) 2018: 53-67

\title{
Penguatan Peran Lingkungan Kerja dan Budaya Organisasi dalam Mengoptimalkan Kinerja Dosen Universitas Islam Negeri Alauddin Makassar melalui Kepuasan Kerja \\ MURTIADI AWALUDDIN* \\ Pascasarjana UIN Alauddin Makassar
}

\begin{abstract}
This research aims to know and analyze influence of work environment and organizational culture on job satisfaction and performance of lecturers at UIN Alauddin Macassar. This research uses explanatory research method, and the population is all the lecturers at UIN ALauddin Macassar. Saturated sample method accumulated to 65 people. Data analysis was done using Structural Equation Modeling (SEM). Results of the analysis show that the work environment and organizational culture influence positively and significantly to job satisfaction and performance of lecturers.
\end{abstract}

Keyword : Work Environment, Organizational Culture, Job Satisfaction and Performance of Lecturers.

*Surel korespondensi penulis: murtiadi.awaluddin@uin-alauddin.ac.id

ISSN-E: 2597-6990 


\section{A. PENDAHULUAN}

Seiring dengan perkembangan ilmu pengetahuan dan teknologi informasi secara tidak langsung telah merubah pola pikir masyarakat untuk lebih meningkatkan wawasan dan keilmuan yang dimiliki dan hal ini bukan saja untuk kebutuhan pribadi semata tetapi juga tuntutan lingkungan global yang semakin kompetitif. Hal ini merupakan tantangan institusi pengelola pendidikan dan pengajaran untuk terus berbenah seiring tuntutan kebutuhan masyarakat yang mendambakan pendidikan yang berkualitas.

Dalam upaya menghasilkan kualitas lulusan yang berkualitas perlu dibarengi dengan kualitas institusi pendidikan juga. Sedangkan kualitas institusi sangat dipengaruhi oleh masukan bagi sistim pendidikan diantaranya adalah mahasiswa, dosen dan fasilitas saranan pendukung proses belajar mengajar. Ketiga faktor tersebut saling tergantung dan mempengaruhi satu sama lain dalam menciptakan proses belajar mengajar yang berhasil.

Salah satu komponen utama yang juga menentukan kualitas pendidikan tinggi adalah Dosen, hal ini sesuai dengan kedudukan dosen sebagai tenaga profesional yang berfungsi meningkatkan martabat dan peran dosen sebagai agen pembelajaran, pengembangan ilmu pengetahuan, teknologi dan seni serta pengabdian kepada masyarakat yang berfungsi untuk meningkatkan mutu pendidikan nasional (UU RI No. 14 tahun 2005, pasal 5). Oleh sebab itu rendahnya kinerja dosen sangat mempengaruhi mutu para lulusan pendidikan tinggi.

Berbagai fenomena kinerja dosen yang biasa muncul pada institusi perguruan tinggi diantaranya adalah beberapa dosen tidak memiliki GBPP dan SAP bahkan yang dipersyaratkan seperti RPS (rencana pembelajaran semester) untuk mata kuliah yang diajarkan, jumlah tatap muka persemester rata-rata tidak pernah mencapai jumlah yang ditetapkan yaitu 16 kali pertemuan persemester, pelaksanaan ujian tengah semester serta ujian akhir yang selalu molor dari jadwal yang telah ditetapkan oleh akademik sehingga pelaporan nilai hasil ujian juga selalu terlambat dan dampaknya kembali pada mahasiswa utamanya yang akan melakukan registrasi atau ke semester berikutnya. Keseluruhan fenomena tersebut biasa terjadi pada beberapa perguruan tinggi tidak terkecuali Fakultas Ekonomi dan Bisnis Islam UIN Alauddin Makassar.

Hal lain yang terkait kinerja dosen ditemukan pada penelitian Sumardi (2007) menemukan fakta-fakta bahwa suasana akademik belum kondusif yang menyebabkan banyak dosen tidak betah berlama-lama tinggal di kampus karena tidak memiliki ruangan khusus dosen, perpustakaan, alat bantu proses belajar mengajar sangat minim ditambah ruangan sholat, kantin dan tempat parkir yang umumnya tidak tersedia ikut meresahkan para dosen (Sumardi,2007). Hasil ini diperkuat pendapat Sedarmayanti (2001) bahwa bahwa lingkungan kerja berupa lingkungan kerja fisik dan lingkungan kerja non fisik merupakan faktor penting yang dapat mempengaruhi kinerja pegawai dalam bekerja. Semakin baik lingkungan kerja tentunya akan mendukung terhadap peningkatan kinerja pegawai dalam melaksanakan tugas. Pengaruh lingkungan kerja terhadap kinerja telah dibuktikan oleh penelitian yang 
dilakukan oleh Haryanti dan Susialisasi (2009) yang membuktikan bahwa lingkungan kerja berpengaruh signifikan terhadap kinerja.

Selain lingkungan kerja, budaya organisasi juga ikut berkontribusi terhadap kinerja pegawai dalam hal ini dosen. Menurut Moeljono dan Sudjatmiko (2007) bahwa budaya organisasi tidak lepas dari strategi organisasi, termasuk visi dan misi organisasi itu sendiri dan merupakan salah satu faktor penting dalam implementasi strategi untuk peningkatan kinerja dalam sebuah organisasi. Budaya ini berkaitan erat dengan nilai-nilai dan norma yang pegang dan berlaku oleh karyawan dalam melakukan pekerjaannya. Budaya yang kuat merupakan landasan kinerja suatu organisasi. Jika terdapat budaya yang tidak kondusif dalam suatu organisasi maka mungkin dapat mempengaruhi pegawai dalam melakukan aktivitasnya dan secara langsung mempengaruhi kinerja masing-masing pegawai. Temuan penelitian Usman (2009) menemukan bahwa budaya organisasi berpengaruh signifikan terhadap kinerja.

Faktor lain yang mempengaruhi kinerja adalah kepuasan kerja. Robbins (2006) mengemukakan bahwa kepuasan kerja yang dirasakan oleh karyawan merupakan faktor yang dapat mempengaruhi kinerja karyawan. Apabila karyawan merasakan kepuasan kerja yang tinggi dalam melaksanakan tugas tentunya akan memberikan kontribusi positif terhadap peningkatan kinerja karyawan. Hasil penelitian Brahmasari dan Suprayetno (2008) membuktikan bahwa kepuasan kerja berpengaruh signifikan terhadap kinerja pegawai.

Berdasarkan latar belakang permasalahan di atas, maka dapat dirumuskan permasalahan penelitian sebagai berikut: 1. Apakah lingkungan kerja, dan budaya organisasi berpengaruh terhadap kepuasan kerja dosen ? 2 . Apakah lingkungan kerja, budaya organisasi berpengaruh langsung terhadap kinerja dosen maupun tidak langsung melalui kepuasan kerja.

\section{B. Kajian Teori}

\section{Lingkungan Kerja}

Lingkungan kerja merupakan salah satu faktor penting dalam menciptakan kinerja pegawai. Karena lingkungan kerja mempunyai pengaruh langsung terhadap karyawan di dalam menyelesaikan pekerjaan yang pada akhirnya akan meningkatkan kinerja organisasi. Suatu kondisi lingkungan kerja dikatakan baik apabila karyawan dapat melaksanakan kegiatan secara optimal, sehat, aman, dan nyaman. Oleh karena itu penentuan dan penciptaan lingkungan kerja yang baik akan sangat menentukan keberhasilan pencapaian tujuan organisasi. Sebaliknya apabila lingkungan kerja yang tidak baik akan dapat menurunkan motivasi serta semangat kerja dan akhirnya dapat menurunkan kinerja karyawan (Sedarmayanti. 2001).

Kondisi dan suasana lingkungan kerja yang baik akan dapat tercipta dengan adanya penyusunan organisasi secara baik dan benar sebagaimana pendapat Sarwoto (1991) bahwa suasana kerja yang baik dihasilkan terutama dalam organisasi yang tersusun secara baik, sedangkan suasana kerja yang kurang baik banyak ditimbulkan oleh organisasi yang tidak tersusun dengan baik pula

Ishak dan Tanjung (2003), manfaat lingkungan kerja adalah menciptakan gairah kerja, sehingga produktivitas dan prestasi kerja meningkat. Sementara 
itu, manfaat yang diperoleh karena bekerja dengan orang-orang yang termotivasi adalah pekerjaan dapat diselesaikan dengan tepat. Yang artinya pekerjaan diselesaikan sesuai standard yang benar dan dalam skala waktu yang ditentukan. Prestasi kerjanya akan dipantau oleh individu yang bersangkutan, dan tidak akan menimbulkan terlalu banyak pengawasan serta semangat juangnya akan tinggi.

\section{Budaya Organisasi}

Robbins (2006) budaya organisasi merupakan sistem makna bersama yang dianut bersama oleh anggota-anggota yang membedakan organisasi itu dari organisasi-organisasi lain. Tampubolon (2003) menyimpulkan budaya organisasi adalah merupakan kesepakatan perilaku karyawan di dalam organisasi yang digambarkan dengan selalu berusaha menciptakan efisiensi, bebas dari kesalahan, perhatian terfokus kepada hasil dan kepentingan karyawan, kreatif dan akurat menjalankan tugas.

Pabundu (2008) menyatakan budaya organisasi adalah seperangkat asumsi dasar dan keyakinan yang dianut oleh anggota-anggota organisasi kemudian dikembangkan dan diwariskan guna mengatasi masalah-masalah adaptasi eksternal dan masalah integrasi internal. Sedangkan menurut Makmuri (2005) budaya organisasi didefinisikan sebagai sebuah corak dari asumsi-asumsi dasar yang ditemukan atau dikembangkan oleh sebuah kelompok tertentu untuk belajar mengatasi problem-problem kelompok dari Adaptasi eksternal dan integrasi internal yang telah bekerja dengan baik

Menurut Kotter (2004), budaya organisasi adalah pengalaman, sejarah, keyakinan dan norma-norma bersama yang menjadi ciri organisasi. Lebih lanjut Werther dan Davis (2003) mengemukakan bahwa budaya organisasi adalah produk dari orang-orang yang berada di dalam organisasi, baik keberhasilan maupun kegagalan serta merupakan refleksi masa lalu dan membentuk masa depan. Sedangkan Donnely (2001) menyatakan bahwa budaya organisasi adalah himpunan dari kepercayaan, harapan dan nilai-nilai yang dianut bersama oleh anggota organisasi dan diwariskan dari suatu generasi ke generasi berikutnya. Budaya organisasi adalah orientasi, pola pikir, persamaan tindakan yang mempengaruhi perilaku, sikap dan efektivitas seluruh karyawan (Hofstede, 1990).

Keseluruhan pengertian budaya organisasi di atas menunjukkan bahwa jantung dari suatu organisasi adalah sikap, keyakinan, kebiasaan, dan pengharapan dari seluruh individu anggota organisasi mulai dari pucuk pimpinan sampai front lines. Dengan demikian tidak ada aktivitas manajemen yang dapat melepaskan diri dari budaya organisasi.

\section{Kepuasan Kerja}

Kepuasan kerja (Job satisfaction), merupakan subset sikap khusus yang dimiliki oleh anggota organisasi, merupakan sikap seseorang terhadap pekerjaannya. Dengan kata lain job satisfaction merupakan respon afektif seseorang terhadap pekerjaan (Taba, 2004) Kepuasan kerja adalah suatu sikap seseorang terhadap pekerjaan sebagai perbedaan antara banyaknya ganjaran yang diterima pekerja dan banyaknya yang diyakini yang seharusnya diterima 
(Robbins, 2006). Sedangkan Umam (2010) menjelaskan bahwa kepuasan kerja merupakan penilaian atau cerminan dan perasaan pekerja terhadap pekerjaannya dan segala sesuatu yang dihadapi lingkungan kerjanya.

Menurut Simamora (2005) mengemukakan bahwa kepuasan kerja adalah seperangkat perasaan pegawai tentang menyenangkan atau tidaknya pekerjaan mereka. Ada perbedaan yang penting antara perasaan ini dengan unsur lainnya dari sikap pegawai. Kepuasan kerja adalah perasaan senang atau tidak senang yang relatif yang berbeda dari pemikiran objektif dan keinginan perilaku. Mathis dan Jacksons (2002) menyatakan bahwa kepuasan adalah keadaan emosi yang positif dari mengevaluasi pengalaman kerja seseorang. Ketidakpuasan kerja akan muncul saat harapan-harapan ini tidak dipenuhi. Sebagai contoh, jika seorang tenaga kerja mengharapkan kondisi kerja yang aman dan bersih, maka tenaga kerja mungkin bisa menjadi tidak puas jika tempat kerja tidak aman dan kotor

\section{Kinerja}

Kinerja berasal dari pengertian performance. Ada pula yang memberikan pengertian performance sebagai hasil kerja atau prestasi kerja, namun sebenarnya kinerja mempunyai makna yang lebih luas, bukan hanya hasil, tetapi termasuk bagaimana proses pekerjaan berlangsung (Wibowo, 2007).

Menurut Hasibuan (2007:52) bahwa kinerja adalah suatu hasil kerja yang dicapai seseorang dalam melaksanakan tugas-tugas yang dibebankan kepadanya yang didasarkan atas kecakapan, pengalaman, dan kesungguhan serta waktu. Dengan demikian kinerja dapat diartikan sebagai hasil kerja secara kualitas dan kuantitas yang dicapai oleh seorang pegawai dalam melaksanakan tugasnya sesuai tanggung jawab yang diberikan kepadanya. Kinerja merupakan suatu sikap dari individu yang bersangkutan dan kelompok terhadap pelatihan mereka dan tentunya terhadap kesediaan bekerja sama dengan orang lain secara menyeluruh sesuai dengan kemampuan atau pengalaman yang mereka miliki untuk kepentingan organisasi

Menurut Rivai dan Sagala (2009) bahwa kinerja adalah perilaku nyata yang ditampilkan setiap orang sebagai prestasi kerja yang dihasilkan oleh karyawan sesuai dengan peranannya dalam perusahaan. Kinerja karyawan merupakan suatu hal yang sangat penting dalam upaya perusahaan untuk mencapai tujuannya. Sedangkan menurut Mashun (2006) kinerja adalah mengenai tingkat pencapaian pelaksanaan kegiatan atau program/kebijakan dalam mewujudkan sasaran, tujuan, misi dan visi yang tertuang dalam strategi perencanaan suatu organisasi.

\section{Hubungan Antar Variabel}

Herzberg dalam Adair (2008) menjelaskan bahwa faktor yang membuat orang mengalami kepuasan di lingkungan kerjanya bukanlah kebalikan dari faktor yang membuatnya tidak puas. Ketidakpuasan di lingkungan kerja disebabkan oleh tidak memadainya lingkungan atau konteks pekerjaan.

Mengingat bahwa kinerja sebenarnya juga merupakan perilaku dalam berusaha, dan perilaku adalah fungsi hubungan antara organisma dan stimuli yang berupa lingkungan baik fisik maupun sosial budaya menuju suatu 
penyempurnaan "accomplishment" (Maier, 1965), maka kinerja terbentuk dari fungsi hubungan seperti itu. Jadi, ada ciri individual dan ciri lingkungan yang membentuk kinerja. Oleh karena itu, kinerja bukan suatu kejadian (suatu kata benda) tetapi suatu aksi (suatu kata kerja), yang terdiri atas sejumlah komponen yang saling terkait dalam suatu proses dan dalam suatu skala waktu (Baird, 1986).

Selanjutnya Parlinda \& Wahyuddin (2008) mengatakan bahwa lingkungan kerja mempunyai pengaruh positif dan signifikan terhadap kinerja karyawan. Dari beberapa temuan di atas maka peneliti bersesuaian pendapat dengan Maier (1965), Baird (1986), dan Parlinda \& Wahyuddin (2008) yang menyatakan bahwa lingkungan kerja mempunya pengaruh terhadap kinerja.

Banyak kesuksesan yang bisa diraih oleh suatu perusahaan karena didukung oleh sebuah budaya yang khas dan kuat tertanam dalam kegiatan operasionalnya. Demikian sebaliknya, cukup banyak kegagalan perusahaan mempertahankan kelangsungan organisasinya disebabkan kurang memperhatikan budaya yang harus dikembangkan (Ndraha,2003).

Dalam beberapa buku banyak dikemukakan dengan tegas bahwa dalam setiap organisasi dan lingkungan kerja pada umumnya tumbuh suatu kebudayaan khusus. Menurut Schein (1985) sesuai yang dikutip oleh Harjana, Budaya Organisasi adalah pola asumsi-asumsi dasar bentukan, temuan atau pengembangan suatu kelompok orang yang telah bekerja dengan cukup baik untuk mengatasi masalah adaptasi eksternal maupun internal, sehingga dapat dianggap perlu untuk diajarkan juga kepada anggota baru sebagai cara yang benar dalam memandang, berpikir dan merasa tentang masalah-masalah yang dihadapinya (Harjana, 1997).

Beberapa penelitian menemukan pengaruh positif dan signifikan kepuasan kerja terhadap kinerja karyawan, antara lain Zulkifli (1996), Haryani (1998) dan Sule (2002). Indikasi hubungan yang signifikan tersebut, telah dilontarkan oleh Miner (1988), bahwa "karyawan yang produktif adalah karyawan yang bahagia". Selanjutnya menurut Adair (2008) mengatakan bahwa seorang individu yang merasa frustasi dan tidak bahagia (puas) dalam lingkungan kerjanya, tidak akan memberikan kinerja yang maksimal (tidak termotivasi).

Herzberg dalam Adair (2008) juga menjelaskan bahwa faktor yang membuat orang mengalami kepuasan di lingkungan kerjanya bukanlah kebalikan dari faktor yang membuatnya tidak puas. Ketidakpuasan di lingkungan kerja disebabkan oleh tidak memadainya lingkungan atau konteks pekerjaan; sebaliknya, kepuasan kerja diperoleh dari kadar pekerjaan, peluang yang diberikannya untuk meraih prestasi (kinerja), mendapat pengakuan, mengembangkan keprofesionalan, dan menumbuhkan kepribadian.

\section{KERANGKA KONSEPTUAL}

Berdasarkan rumusan masalah dan kajian teoritik maka kerangka konsep yang diajukan di tampilkan pada Gambar 1 berikut : 


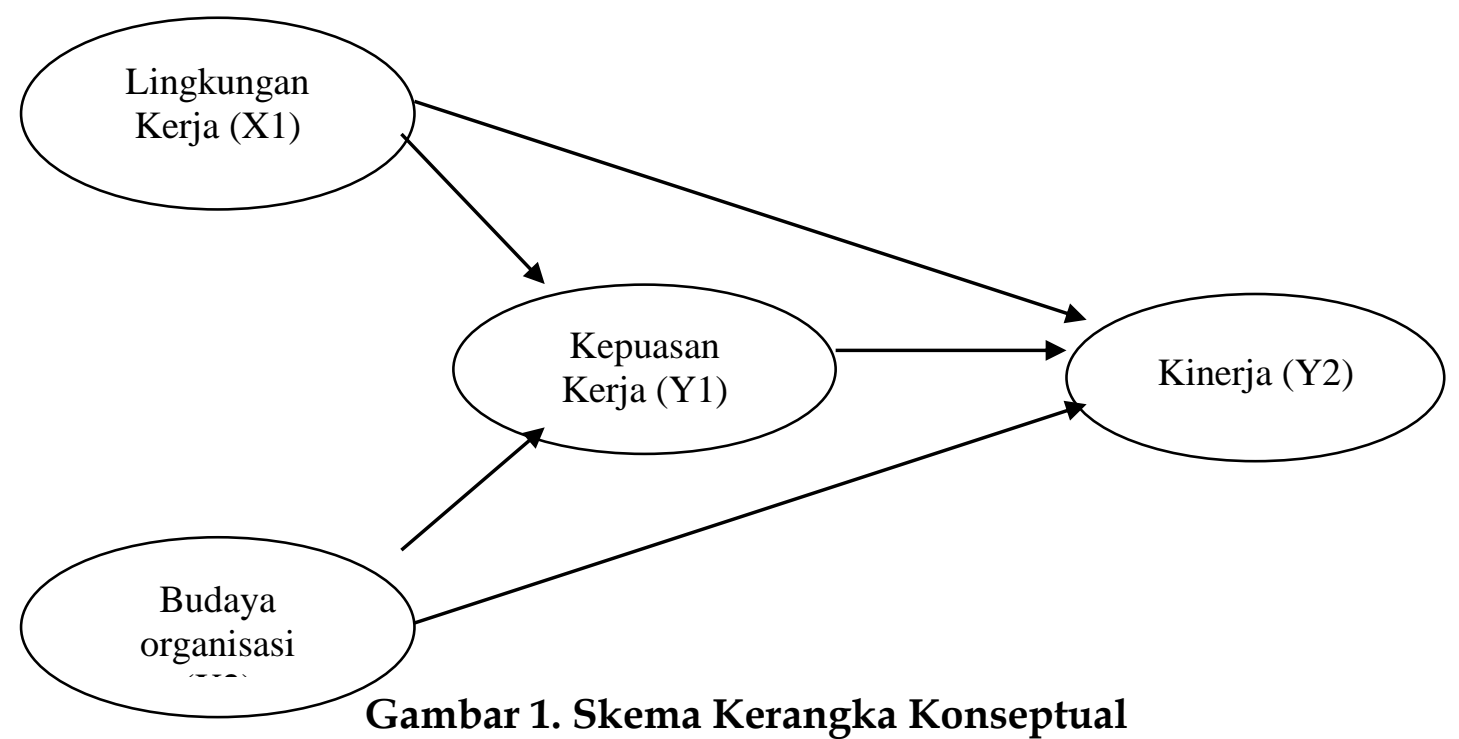

\section{HIPOTESIS}

Berdasarkan rumusan permasalahan dan kajian teoritik sehingga hipotesis yang diajukan adalah: 1 . lingkungan kerja, dan budaya organisasi berpengaruh langsung positif dan signifikan terhadap kepuasan kerja dosen 2. lingkungan kerja, budaya organisasi berpengaruh langsung dan signifikan terhadap kinerja dosen maupun tidak langsung melalui kepuasan kerja.

\section{E. METODE PENELITIAN}

Berdasarkan jenis penelitian, maka penelitian ini merupakan penelitian yang menjelaskan hubungan kausal antara variabel atau yang disebut penelitian eksplanatori. Selain itu, penelitian ini termasuk dalam penelitian deskriptif. Populasi penelitian ini adalah seluruh dosen aktif yang mengajar di UIN Alauddin Makassar sedangkan populasi target adalah seluruh dosen yang mengajar pada Fakultas Ekonomi dan Bisnis Islam UIN Alauddin Makassar baik pns maupun non pns yang berjumlah 65 orang. Teknik sampling yang digunakan adalah sampel jenuh sehingga menggunakan seluruh populasi sebagai sampel. Analisis data dilakukan dengan menggunakan model persamaan struktural atau Structural Equation Modeling (SEM). Pada penelitian ini, jenis data yang digunakan bersifat kualitatif dan kuantitatif. Sumber data yang digunakan dalam penelitian ini bersifat data primer. Pada penelitian ini teknik yang digunakan meliputi : (1) Observasi, (2) Wawancara yang digunakan adalah wawancara mendalam (indepth interview) atau wawancara tidak terstruktur. (3) Kuisioner disusun dalam bentuk pertanyaan pertanyaan tertulis yang diberikan kepada responden. (4) Dokumentasi yang dibutuhkan adalah berbagai dokumen tertulis maupun tidak tertulis yang menunjukkan atau menggambarkan data dan informasi penting yang berhubungan dengan penelitian.

Metode analisis yang digunakan dalam penelitian ini adalah model persamaan struktural atau Structural Equation Modeling (SEM) untuk 
mengetahui hubungan kausal antar variabel laten yang terdapat dalam persamaan struktural. Alat analisis yang digunakan adalah dengan bantuan reduced form dan program aplikasi statistik AMOS ver. 20 dan SPSS ver 17.0. Adapun reduced form yang digunakan berdasarkan kerangka konseptual sebagai berikut:

1. Pengaruh pengaruh lingkungan kerja dan budaya organisasi terhadap kepuasan kerja: $Y_{1}=\alpha_{0}+\alpha_{1} X_{1}+\alpha_{2} X_{2}+\varepsilon_{1}$ Dimana: $\alpha_{0} \alpha_{1}$, dan $\alpha_{2}$ adalah parameter yang akan ditaksir dan $\varepsilon_{1}$ adalah error term kepuasan kerja .

2. Pengaruh lingkungan kerja, budaya organisasi dan kepuasan kerja terhadap kinerja dosen: $Y_{2}=\beta_{0}+\beta_{1} X_{1}+\beta_{2} X_{2}+\beta_{3} Y_{1}+\varepsilon_{2}$.Dimana: $\beta_{0}, \beta_{1}, \beta_{2}$ dan $\beta_{3}$ adalah parameter yang akan ditaksir dan $\varepsilon_{2}$ adalah error term kinerja dosen

\section{F. HASIL PENELITIAN}

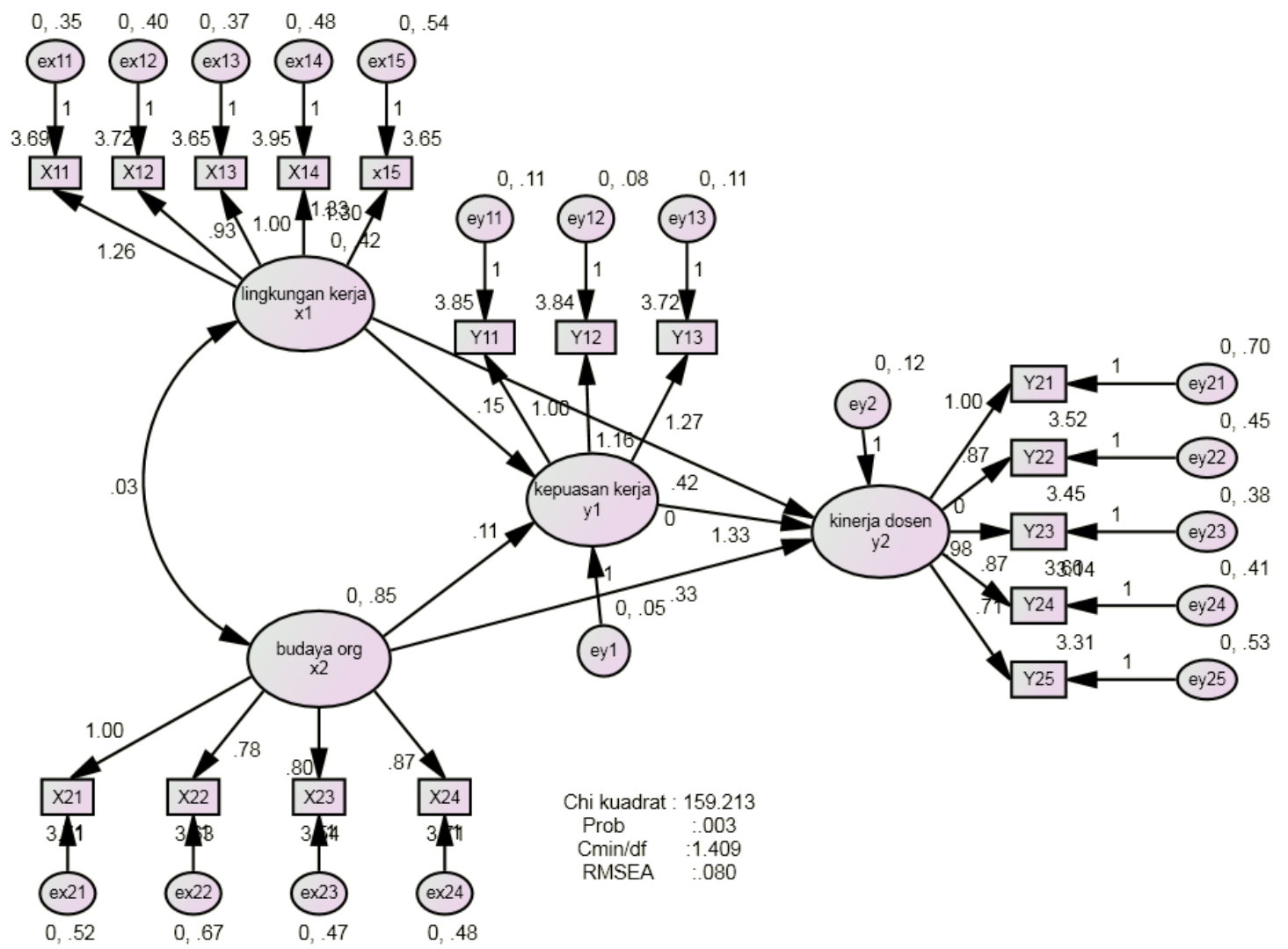

Gambar 2. Skema Pengaruh Keseluruhan Variabel

Untuk memudahkan dalam menganalisis hubungan fungsional antar variabel kemudian nilai koefisien disusun dalam bentuk Tabel sebagaimana di tampilkan pada Tabel di lampiran 2:

\section{Pengaruh Lingkungan Kerja $\left(\mathrm{X}_{1}\right)$ Terhadap Kepuasan Kerja (Y1)}

Koefisien pengaruh variabel Lingkungan Kerja $\left(X_{1}\right)$ terhadap Kepuasan Kerja (Y1) sebesar 0.154 dengan nilai $\mathrm{t}$ sebesar 2.253 pada taraf signifikansi 0,024. Koefisien tersebut menunjukkan bahwa variabel Lingkungan Kerja $\left(\mathrm{X}_{1}\right)$ berpengaruh positif terhadap Kepuasan Kerja (Y1). Ini berarti bahwa perbaikan 
Lingkungan Kerja $\left(\mathrm{X}_{1}\right)$, akan diikuti dengan perbaikan Kepuasan Kerja (Y1) dengan asumsi faktor-faktor lain yang mempengaruhi besar kecilnya Kepuasan Kerja (Y1) dianggap konstan. Nilai statistik $t$ hitung pengaruh Lingkungan Kerja $\left(\mathrm{X}_{1}\right)$ terhadap Kepuasan Kerja (Y1) sebesar 2.253 dengan signifikansi 0.024 atau di bawah 0,05. Ini berarti Lingkungan Kerja $\left(X_{1}\right)$ berpengaruh signifikan terhadap Kepuasan Kerja (Y1) .

\section{Pengaruh Budaya Organisasi $\left(\mathrm{X}_{2}\right)$ Terhadap Kepuasan Kerja (Y1)}

Koefisien pengaruh variabel budaya organisasi $\left(\mathrm{X}_{2}\right)$ terhadap Kepuasan Kerja (Y1) sebesar 0.114 dengan nilai $t$ sebesar 2.367 pada taraf signifikansi 0,018 . Koefisien tersebut menunjukkan bahwa variabel budaya organisasi $\left(\mathrm{X}_{2}\right)$ berpengaruh positif terhadap Kepuasan Kerja(Y1). Ini berarti bahwa perbaikan budaya organisasi $\left(\mathrm{X}_{2}\right)$, akan diikuti dengan perbaikan Kepuasan Kerja (Y1) dengan asumsi faktor-faktor lain yang mempengaruhi besar kecilnya Kepuasan Kerja (Y1) dianggap konstan. Nilai statistik $t$ hitung pengaruh budaya organisasi $\left(\mathrm{X}_{2}\right)$ terhadap Kepuasan Kerja (Y1) sebesar 2.367 dengan signifikansi 0.018 atau di bawah 0,05 . Ini berarti budaya organisasi $\left(\mathrm{X}_{2}\right)$ berpengaruh signifikan terhadap Kepuasan Kerja (Y1) .

\section{Pengaruh Lingkungan Kerja $\left(\mathrm{X}_{1}\right)$ Terhadap Kinerja dosen $\left(\mathrm{Y}_{2}\right)$}

Koefisien pengaruh variabel Lingkungan Kerja $\left(X_{1}\right)$ terhadap Kinerja dosen $\left(\mathrm{Y}_{2}\right)$ sebesar 0.424 dengan nilai $\mathrm{t}$ sebesar 2.546 pada taraf signifikansi 0,011 . Koefisien tersebut menunjukkan bahwa variabel Lingkungan Kerja $\left(\mathrm{X}_{1}\right)$ berpengaruh positif terhadap Kinerja dosen (Y2). Ini berarti bahwa perbaikan Lingkungan Kerja $\left(X_{1}\right)$, akan diikuti dengan perbaikan Kinerja dosen $\left(Y_{2}\right)$ dengan asumsi faktor-faktor lain yang mempengaruhi besar kecilnya Kinerja dosen (Y2) dianggap konstan. Nilai statistik t hitung pengaruh Lingkungan Kerja $\left(\mathrm{X}_{1}\right)$ terhadap Kinerja dosen (Y2) sebesar 2.546 dengan signifikansi 0.011 atau di bawah 0,05. Ini berarti Lingkungan Kerja $\left(X_{1}\right)$ berpengaruh signifikan terhadap Kinerja dosen (Y2).

\section{Pengaruh Budaya Organisasi $\left(\mathrm{X}_{2}\right)$ Terhadap Kinerja Dosen $\left(\mathrm{Y}_{2}\right)$}

Koefisien pengaruh variabel budaya organisasi $\left(\mathrm{X}_{2}\right)$ terhadap Kinerja dosen (Y2) sebesar 0.332 dengan nilai $t$ sebesar 2.819 pada taraf signifikansi 0,005 . Koefisien tersebut menunjukkan bahwa variabel budaya organisasi $\left(\mathrm{X}_{2}\right)$ berpengaruh positif terhadap Kinerja dosen (Y2). Ini berarti bahwa perbaikan budaya organisasi $\left(\mathrm{X}_{2}\right)$, akan diikuti dengan perbaikan Kinerja dosen (Y2) dengan asumsi faktor-faktor lain yang mempengaruhi besar kecilnya Kinerja dosen (Y2) dianggap konstan. Nilai statistik $t$ hitung pengaruh budaya organisasi $\left(\mathrm{X}_{2}\right)$ terhadap Kinerja dosen $(\mathrm{Y} 2)$ sebesar 2.819 dengan signifikansi 0.005 atau di bawah 0,05 . Ini berarti budaya organisasi $\left(\mathrm{X}_{2}\right)$ berpengaruh signifikan terhadap Kinerja dosen (Y2).

\section{Pengaruh Kepuasan Kerja (Y1) Terhadap Kinerja dosen (Y2)}

Koefisien pengaruh variabel Kepuasan Kerja (Y1) terhadap Kinerja dosen (Y2) sebesar 1.329 dengan nilai $t$ sebesar 2.697 pada taraf signifikansi 0,007. Koefisien tersebut menunjukkan bahwa variabel Kepuasan Kerja (Y1) 
berpengaruh positif terhadap Kinerja dosen (Y2). Ini berarti bahwa perbaikan Kepuasan Kerja (Y1), akan diikuti dengan perbaikan Kinerja dosen (Y2) dengan asumsi faktor-faktor lain yang mempengaruhi besar kecilnya Kinerja dosen (Y2) dianggap konstan. Nilai statistik $t$ hitung pengaruh Kepuasan Kerja (Y1) terhadap Kinerja dosen (Y2) sebesar 2.697 dengan signifikansi 0.007 atau di bawah 0,05. Ini berarti Kepuasan Kerja (Y1) berpengaruh signifikan terhadap Kinerja dosen (Y2).

\section{PEMBAHASAN}

\section{Pengaruh Lingkungan kerja terhadap Kepuasan kerja}

Pengaruh variabel lingkungan kerja terhadap kepuasan kerja adalah positif. ini berarti bahwa perbaikan lingkungan kerja akan diikuti dengan peningkatan kepuasan kerja dosen dengan asumsi faktor-faktor lain yang mempengaruhi besar kecilnya lingkungan kerja dianggap konstan. Hasil pengujian menunjukkan lingkungan kerja berpengaruh signifikan terhadap kepuasan kerja.

Temuan penelitian ini membuktikan bahwa lingkungan kerja pada UIN Alauddin Makassar utamanya pada fakultas ekonomi dan bisnis islam, sangat penting untuk diperhatikan oleh unsur pimpinan. Lingkungan kerja yang memadai bagi dosen dapat mendukung peningkatan kepuasan dosen dan berdampak pada kinerja dosen. Temuan penelitian ini didukung oleh pendapat Sarwoto (1991) yang menyatakan bahwa lingkungan kerja adalah suasana kerja yang baik dihasilkan terutama dalam organisasi yang tersusun secara baik, sedangkan suasana kerja yang kurang baik banyak ditimbulkan oleh organisasi yang tidak tersusun dengan baik pula. Hasil penelitian ini juga sejalan dengan Awaluddin (2006)

Menurut Robbins (1996) ada empat faktor penting yang mendorong kepuasan kerja adalah kerja yang secara mental menantang, ganjaran yang pantas, kondisi kerja yang mendukung, dan rekan kerja yang mendukung dan kesesuaian pribadi dengan pekerjaan. Lingkungan kerja yang mendukung produktivitas kerja akan menimbulkan kepuasan kerja bagi pekerja dalam suatu organisasi. Lingkungan kerja adalah kekuatan yang mendorong semangat yang ada di dalam maupun di luar dirinya baik itu yang berupa reward maupun punishment. sehingga Herberg dalam Luthans (2003) menyatakan bahwa pada manusia terdapat enam faktor pemuas. 1). prestasi kerja yang diraih (achievement). 2). pengakuan orang lain (recognition). 3). tanggung jawab (responsibility). 4). peluang untuk maju (advancement). 5). kepuasan kerja itu sendiri (the work itself). 6). dan pengembangan karir (the possibility of growth).

\section{Pengaruh Budaya Organisasi terhadap Kepuasan kerja}

Pengaruh variabel budaya organisasi terhadap kepuasan kerja adalah positif. ini berarti bahwa peningkatan budaya organisasi akan diikuti dengan peningkatan kepuasan kerja dengan asumsi faktor-faktor lain yang mempengaruhi besar kecilnya budaya organisasi dianggap konstan. Hasil penelitian ini membuktikan bahwa budaya organisasi di UIN Alauddin 
Makassar, utamanya fakultas ekonomi dan bisnis islam berpengaruh positif dan signifikan terhadap kepuasan kerja dosen, artinya budaya organisasi merupakan suatu konsep yang dapat dijadikan sarana untuk mengukur kesesuaian dari tujuan organisasi baik bagi pegawai maupun dosen dalam melaksanakan tugas.

Temuan penelitian ini didukung oleh pendapat Marcoulides dan Heck, 1993 dalam Brahmasari (2004) yang menyatakan bahwa budaya organisasi merupakan faktor yang mempengaruhi kepuasan kerja karyawan, artinya budaya organisasi merupakan suatu konsep yang dapat dijadikan sarana untuk mengukur kesesuaian dari tujuan organisasi, strategi dan organisasi tugas, serta dampak yang dihasilkan, karena adanya budaya yang baik dalam internal organisasi tentunya akan mendorong terciptanya kepuasan kerja yang tinggi pada dosen dalam beraktifitas.

Menurut Emmons (1999) mengungkapkan bahwa individu merasa tidak nyaman dalam suatu lingkungan akan mengalami ketidakberdayaan, kekhawatiran. Sebaliknya kalau ia merasa nyaman dengan lingkungannya ia akan memperlihatkan sifat positif dan memilih tinggal lebih lama dalam lingkungan tersebut. Lebih jauh, kesesuaian antara individu dengan budaya organisasi dimana ia bekerja, akan menimbulkan kepuasan kerja, komitmen kerja dan akan mendorong individu untuk bertahan pada suatu perusahaan dan karir dalam jangka panjang. (Kotter dan Heskett, 1997, Wallach, 1983, O'Reilley III et all , 1991).

Berdasarkan hasil ini sehingga hipotesis 1 yang menyatakan : lingkungan kerja, dan budaya organisasi berpengaruh langsung positif dan signifikan terhadap kepuasan kerja dosen diterima.

\section{Pengaruh Lingkungan kerja terhadap Kinerja dosen}

Pengaruh variabel lingkungan kerja terhadap kinerja dosen adalah positif. ini berarti bahwa peningkatan lingkungan kerja akan diikuti dengan peningkatan kinerja dosen dengan asumsi faktor-faktor lain yang mempengaruhi besar kecilnya lingkungan kerja dianggap konstan. Hasil pengujian menunjukkan lingkungan kerja berpengaruh signifikan terhadap kinerja dosen. Temuan penelitian ini membuktikan bahwa ukuran tingkat pencapaian prestasi kerja dosen UIN Alauddin Makassar dalam melaksanakan tugas sehari-hari dipengaruhi oleh penilaian pegawai terhadap lingkungan organisasi sebagai tempat bekerja dosen setiap hari. Apabila pegawai merasakan lingkungan kerja fisik dan non fisik yang baik pada dosen UIN Alauddin Makassar akan dapat meningkatkan kinerja pegawai dalam melaksanakan tugasnya. Temuan penelitian ini didukung oleh pendapat Sedarmayanti (2001:80) menjelaskan bahwa lingkungan kerja berupa lingkungan kerja fisik dan lingkungan kerja non fisik merupakan faktor penting yang dapat mempengaruhi kinerja pegawai dalam bekerja. Semakin baik lingkungan kerja tentunya akan mendukung terhadap peningkatan kinerja pegawai dalam melaksanakan tugas. Temuan ini juga sejalan dengan murtiadi awaluddin (2016) bahwa lingkungan kerja berpengaruh signifikan terhadap kinerja dosen. Menurut Gibson (2004) salah satu faktor yang mempengaruhi 
kinerja adalah Faktor-faktor psikologis terdiri dari: persepsi, peran, sikap,kepribadian, motivasi, lingkungan kerja dan kepuasan kerja. Soedarmayanti (2003) menyatakan bahwa Lingkungan kerja yang menyenangkan bagi karyawan melalui pengikatan hubungan yang harmonis dengan atasan, rekan kerja, maupun bawahan serta didukung oleh sarana dan prasarana yang memadai yang ada di tempat bekerja akan membawa dampak yang positif bagi karyawan, sehingga kinerja karyawan dapat meningkat.

\section{Pengaruh Budaya Organisasi terhadap Kinerja dosen}

Pengaruh variabel budaya organisasi terhadap kinerja dosen adalah positif. ini berarti bahwa peningkatan budaya organisasi akan diikuti dengan peningkatan kinerja dosen dengan asumsi faktor-faktor lain yang mempengaruhi besar kecilnya budaya organisasi dianggap konstan. Hasil pengujian menunjukkan budaya organisasi berpengaruh signifikan terhadap kinerja dosen, Kotter dan Heskett (1997) mengatakan bahwa budaya yang kuat dapat menghasilkan efek yang sangat mempengaruhi individu dan kinerja, bahkan dalam suatu lingkungan bersaing pengaruh tersebut dapat lebih besar daripada faktor- faktor lain seperti struktur organisasi, alat analisis keuangan, kepemimpinan dan lain -lain. Budaya organisasi yang mudah menyesuaikan dengan perubahan jaman (adaptif) adalah yang dapat meningkatkan kinerja. Menurut Mangkunegara (2007) faktor lingkungan kerja organisasi sangat menunjang bagi individu dalam mencapai kinerja. Faktor lingkungan organisasi yang dimaksud antara lain uraian jabatan yang jelas, otoritas yang memadai, target kerja yang menantang, pola komunikasi yang efektif, hubungan kerja yang harmonis, iklim kerja yang respek dan dinamis, peluang berkarir dan fasilitas kerja yang relatif memadai.

\section{Pengaruh kepuasan kerja terhadap Kinerja dosen}

Pengaruh variabel kepuasan kerja terhadap kinerja dosen adalah positif. ini berarti bahwa peningkatan kepuasan kerja akan diikuti dengan peningkatan kinerja dosen dengan asumsi faktor-faktor lain yang mempengaruhi besar kecilnya kepuasan kerja dianggap konstan. Hasil pengujian menunjukkan kepuasan kerja berpengaruh signifikan terhadap kinerja dosen, menurut Robbins (1996), dalam pernyataannya bahwa seorang pekerja yang bahagia adalah seorang pekerja yang produktif " (bagi individu). Jika diterapkan dalam suatu organisasi maka dapat dikatakan organisasi dengan karyawan yang terpuaskan cenderung lebih efektif, sehingga produktivitas semakin meningkat. Menurut Siagian (1995), kepuasan kerja ialah sikap umum seseorang terhadap pekerjaannya. Artinya secara umum dapat dirumuskan bahwa seseorang yang memiliki rasa puas terhadap pekerjaannya akan mempunyai sikap yang positif terhadap organisasi dimana ia berkarya.

Berdasarkan hasil ini sehingga hipotesis 2 yang menyatakan. lingkungan kerja, budaya organisasi berpengaruh langsung dan signifikan terhadap kinerja dosen maupun tidak langsung melalui kepuasan kerja diterima. 


\section{Implikasi Hasil Penelitian}

Implikasi teori yang dapat dikemukakan dalam penelitian ini bahwa untuk mengoptimalkan kinerja dosen secara berkala dapat menggunakan model enguatan Peranp lingkungan kerja dan budaya organisasi dalam mengoptimalkan kinerja dosen universitas islam negeri alauddin makassar melalui kepuasan kerja Hasil penelitian ini menemukan bahwa saat kinerja dosen menjadi optimal adalah sebagai akibat dari kondusifnya lingkungan kerja serta membaiknya budaya organisasi sehingga berdampak pada peningkatan kepuasan kerja dan pada akhirnya terjadi peningkatan pada kinerja dosen. Implikasi Temuan empirik pada penelitian ini adalah didapatkannya suatu formulasi peningkatan kinerja dosen melalui perbaikan lingkungan kerja dan budaya organisasi yang dapat meningkatkan kepuasan kerja.

\section{Simpulan}

Terdapat pengaruh signifikan lingkungan kerja dan budaya organisasi terhadap kepuasan kerja dosen, sehingga perbaikan lingkungan kerja, perbaikan budaya organisasi akan menciptakan peningkatan kepuasan kerja. Ini mengindikasikan bahwa jika suatu perguruan tinggi ingin meningkatkan kepuasan kerja dosennya dapat dilakukan dengan melakukan perbaikan lingkungan kerja dan perbaikan budaya organisasi perguruan tingginya.

Terdapat pengaruh lingkungan kerja dan budaya organisasi terhadap kinerja dosen, sehingga perbaikan lingkungan kerja, perbaikan budaya organisasi akan menciptakan peningkatan kinerja dosen. Ini mengindikasikan bahwa jika suatu perguruan tinggi ingin meningkatkan kinerja dosennya dapat dilakukan dengan perbaikan lingkungan kerja dan perbaikan budaya organisasi perguruan tingginya.

\section{Saran}

Secara total lingkungan kerja, budaya organisasi dan kepuasan kerja berpengaruh positif dan signifikan terhadap kinerja dosen. Kondisi ini dapat dijadikan rujukan formulasi peningkatan kinerja dosen manakala perguruan tinggi ingin mewujudkan kinerja dosen yang profesional.

\section{DAFTAR PUSTAKA}

Angrist, Joshua D. \& Acemoglu, Daron. 2001. Consequences of Employment Protection? The Case of the Americans with Disabilities Act. MIT. USA

As`ad, Moh., 1995. Psikologi Industri. Cetakan Kelima.Penerbit Liberty, Yogjakarta

Awaluddin, Murtiadi. "Pengaruh Budaya Organisasi, Kepuasan dan Lingkungan Kerja Terhadap Kinerja Dosen UIN Alauddin Makassar." In Assets, vol. 6, no. 1, pp. 116-125. 2016. 
Awaluddin, M. (2013). Pengaruh Independensi Dan Kompetensi Auditor Terhadap Kepuasan Kerja Dan Kinerja Auditor. Jurnal Kompetensi dan Independensi.

Awaluddin, M. (2013). Pengaruh Independensi dan Kompetensi Auditor Terhadap Kepuasan Kerja dan Kinerja Auditor Inspektorat Kota Makassar. Jurnal Assets, 3.

Betts, Julian R, 2001. The Impact of School Resources on Women's Earnings and Education Attaiment: Findings from the National Longitudinal Survey of Young Women; Journal Labor Economics, Vol. 19 (635-657), The 16 University Chicago. of Chicago Press

Burki, SJ, G.E. Perry dan W.R. Dillinger, 1999. Beyond the Center: Dezentralizing the State. The World Bank, Washington DC

Djojonegoro, Wardiman. 2004, Budaya Perusahaan, PT. Media Kompetindo, Jakarta

Emmons, R. 1999. The Psychology of Ultimate Concerns: Motivation and Spirituality in Personality. New York: Guilford

Gibson, James dkk. 2004. Organizations; Behavior, Structures, Processes. Boston: McGrawhill

Katzel,R.A.,D.E.Tompson, dan R.A.Guzzo, 1992, "How Job Satisfaction and Job Performance Are and Are Not Linked" Dalam C.J.Cranny,P.C.Smith,dan E.F.Stone (ed), Job Satisfaction (New York:Lexington Books)

Kotter, JP dan J.L. Heskett, 1997. Corporate Culture and Performance, Jakarta : PT. Prenhallind,

Locke,E.A, 1976, “The Nature and Causes of Job Satisfaction," Dalam M.D. Dunnette (ed), Handbook of Industrial and Organizational Psychology (Chicago:Rand McNally).

Lopez, Elsa, 1982, A Test of The Self-Consistency Theory of The Job Performance-job Satisfaction Relationship, Academy of Management Journal, Vol.25, 1982.

Luthan, Fred. 2003. Organization Behavior, Singapore: McGraw-Hill Books Coy

Mangkunegara, A.A. Anwar Prabu. 2007, Manajemen sumber daya manusia perusahaan, Bandung : Remaja Rosdakarya

O'Reilley III, Charles, and Chatman, Jenífer.,a.nd Caldwell,david F. 1991. "People and Organizationaì Culture: A Profile Comparìson Approach to Assessing Person Organizational Fit". A cademy of Management Journal. Vol.34. No. 3. pp. 487-515.

Robbins, Stephen P, 1996, Organazation Theory: Structure, Design, and Applications, Prentice Hall, Inc, A Division of Simon and Schuster, Englewood Cliffs, 1990, Alih Bahasa Yusuf Udaya, Cetakan Kedua, Penerbit Arcan, Jakarta.

Sedarmayanti, 2003, Sumber Daya Manusia dan Produktivitas Kerja, Bandung, Penerbit Mandar Maju. 
Jurnal Manajemen, Ide dan Inspirasi Juni, Vol. 5 No.1, 2018 Hal. 53-67

Siagian, Sondang P.,1995, Teori, Motivasi dan Aplikasinya, Cetakan Kedua, Rineka Cipta, Jakarta

Strauss, George and Leonard Sayles, 1990, Personnel-The Human Problems of Management, Prentice-Hall, New Jersey, USA, 1980, Terjemahan Grace M. Hadikusuma dan Rochmulyati Hamzah, Jilid I dan II, Penerbit PT. Pustaka Binaman Pressindo, Jakarta.

Sumardi, 2007, Keterkaitan Penyelarasan Proses Manajemen dengan Atmosfir Akademik, Komitmen Organisasi, Mutu Layanan dan Kinerja Perguruan Tinggi di Makassar, Disertasi, Pascasarjana Universitas Hasanuddin, Makassar

Wallach E. J., 1983, "Individual and Organizations: The Culture Match", Training and Development Journal, 37: 2, 29-36.

White, B.J. 1988. "The Internalization of Business: One Company's Response", Academy of Management Executive 2, no.1:29-32. 